\title{
PENGARUH PEMBERIAN RAGI ROTI DENGAN DOSIS YANG BERBEDA TERHADAP PERTUMBUHAN POPULASI Brachionus plicatilis
}

\author{
Effect of Different Levels of Bakers Yeast on Population Growth \\ Brachionus plicatilis
}

\author{
Iksan $^{\left.1^{*}\right)}$, Muhammad Junaidi ${ }^{2)}$, Alis Mukhlis ${ }^{2)}$. \\ ${ }^{1)}$ Alumni Program Studi Budidaya Perairan, Universitas Mataram \\ ${ }^{2)}$ Staf Pengajar Program Studi Budidaya Perairan, Universitas Mataram \\ Jl. Pendidikan No. 37 Mataram, NTB. \\ *) Iksan_fishery@yahoo.co.id
}

\begin{abstract}
This study aims to determine the best dose of bakers yeast in culture Brachionus plicatilis. The research was conducted in July-September 2015 in the Mandiri Laboratory of BTN Puri Meninting West Lombok District. This experiment uses a completely randomized design ( CRD ), which consists of 6 treatments and repeated 3 times, in order to obtain 18 units of trial that treatment A : without feed, treatment B : feed Nannochloropsis spp., treatment C : $7.5 \mathrm{mg} / \mathrm{L}$, treatment D : $15.0 \mathrm{mg} / \mathrm{L}$, treatment $\mathrm{E}: 22.5 \mathrm{mg} / \mathrm{L}$, and treatment F : $30.0 \mathrm{mg} / \mathrm{L}$. The results showed that the difference in the level of baker's yeast significantly affect the population growth of Brachionus plicatilis, which obtained the highest population density in the yeast dose of $30.0 \mathrm{mg} / \mathrm{L}$ of 90 individuals $/ \mathrm{mL}$
\end{abstract}

Key word : bakers yeast, population growth, Brachionus plicatilis

\begin{abstract}
ABSTRAK
Penelitian ini bertujuan untuk mengetahui dosis ragi roti yang terbaik dalam kultur Brachionus plicatilis. Penelitian dilaksanakan pada bulan Juli - September 2015 di Laboratorium Mandiri BTN Puri Meninting Kabupaten Lombok Barat. Penelitian ini menggunakan Rancangan Acak Lengkap (RAL) yang terdiri dari 6 perlakuan dan diulang sebanyak $3 \mathrm{kali}$, sehingga diperoleh 18 unit percobaan yaitu perlakuan A : tanpa pakan, perlakuan B : pakan Nannochloropsis spp., perlakuan C : 7,5 mg/L, perlakuan D : 15,0 $\mathrm{mg} / \mathrm{L}$, perlakuan E : 22,5 mg/L, dan perlakuan F : 30,0 mg/L. Hasil penelitian menunjukan bahwa perbedaan dosis ragi roti berpengaruh nyata terhadap pertumbuhan populasi Brachionus plicatilis, dimana kepadatan populasi tertinggi diperoleh pada dosis ragi 30,0 $\mathrm{mg} / \mathrm{L}$ yaitu 90 individu/mL
\end{abstract}

Kata kunci : ragi roti, pertumbuhan populasi, Brachionus plicatilis, 


\section{PENDAHULUAN}

Dewasa ini budidaya perikanan berkembang sangat pesat seiring dengan permintaan yang semakin besar karena minat konsumen yang terus bertambah (Khaeriyah, 2014). Usaha budidaya ini tidak terlepas dari kegiatan pembenihan sebagai penyedia benih. Penyediaan benih secara kuantitas dan kualitas serta berkesinambungan harus diperhatikan dengan baik. Salah satu faktor yang sering dihadapi dalam kegiatan pembenihan ikan yaitu sulitnya menyediakan pakan alami secara kontinyu yang dimanfaatkan sebagai makanan awal larva ketika kuning telur atau cadangan makanan habis. Larva yang kehabisan kuning telur sangat membutuhkan pemasokan makanan yang selalu tersedia disekitarnya, jika makanan telat diberikan maka larva akan mati.

Branchionus plicatilis merupakan salah satu jenis rotifera yang telah digunakan secara luas dalam kegiatan pembenihan sebagai pakan berbagai larva ikan dan kerang laut (Lubzens et al., 1989). Rotifera merupakan salah satu golongan zooplankton yang mulai populer dimanfaatkan sebagai pakan alami berbagai larva fauna laut sejak 1960 (Dheart, 1996). Beberapa keunggulan yang dimiliki rotifera sebagai pakan larva diantaranya berukuran kecil $(5-200 \mu \mathrm{m})$, bernerang lambat sehingga mudah dimangsa larva, mudah dicerna, mudah dikembangbiakkan, mempunyai kandungan gizi yang cukup tinggi serta dapat diperkaya dengan asam lemak dan antibiotik (Lubzens et al., 1989). Selain itu, rotifera berpeluang besar dijadikan biokapsul alami bagi larva, karena dapat mentransfer senyawa-senyawa dari lingkungan ke tubuh larva (Sahandi dan Jafaryan, 2011), dan mengandung sumber senyawa-senyawa bioaktif penting yang belum banyak dieksplorasikan.

Keberhasilan dalam kultur rotifera akan sangat tergantung pada jenis dan kualitas pakan yang diberikan (Dhert et al., 2001; Melianawati et al., 2006). Jenis pakan yang biasa diberikanan untuk rotifera antara lain fitoplankton, ragi dan emulsi bahan pengkaya (Dheart, 1996). Beberapa jenis fitoplankton yang dapat digunakan sebagai pakan rotifera diantaranya Chlorella, Dunaliela, Nannochloropsis sp., Tetraselmis sp., Monochrysis (Isnansetyo dan Kurniastuty, 1995; Warouw, 2010), Isochrysis sp., dan Pavlova sp. (Widjaja, 2004). Penggunaan pakan fitoplankton sering kali mengalami beberapa kesulitan seperti penyediaan dan penanganan fitoplankton yang kurang teliti, sehingga akan dapat mengakibatkan ketidak murnian bahkan menjadikan fitoplankton sebagai media penyakit (Haryanti, 2002). Selain itu, kendala yang dihadapi dalam kultur fitoplankton khususnya pada produksi secara massal ialah ketergantungan terhadap kondisi dan musim tertentu, bila tidak sesuai maka kultur fitoplankton akan mengalami kendala dan kematian.

Ragi roti (bakery yeast) merupakan jenis pakan alternatif yang dapat digunakan apabila kultur fitoplankton tidak mencukupi, sehingga kebutuhan pakan rotifera dapat dipenuhi (Khaeriyah, 2014), atau dapat ditambahkan emulsi bahan pengkaya lainnnya seperti Scott's emulsion (Astuti et al., 2012), dan vitamin (Chilmawati dan Suminto, 2009; Fitriani et al., 2013). Penggunaan ragi sebagai pakan rotifera dalam penerapannya relatif mudah dan ketersediannya cukup stabil di pasaran serta dapat disimpan lebih lama (Dheart, 1996; Sahandi dan Jafaryan, 2011). Ragi juga dapat berfungsi sebagai 
probiotik yang menguntungkan karena dapat mengurangi biya produksi, dan dapat menjadi substrat organik yang dapat meningkatkan pertumbuhan Brachionus plicatilis. Ragi memiliki kandungan karbohidrat dan protein yang tinggi yang dapat digunakan oleh Brachionus plicatilis untuk pertumbuhan (Pranata, 2009). Selain itu, ragi yang digunakan sebagai makanan Brachionus plicatilis juga dapat berfungsi sebagai probiotik dan sebagai sumber nutrisi untuk menambah nilai gizi hewan air Dhert et al. (2001).

Menurut Wohlschlag et al. (1990) penggunaan ragi $0.6-1.0 \mathrm{~g} / 10^{6}$ individu Brachionus plicatilis dan minyak ikan 2-3 $\mathrm{ml} / 10^{6}$ individu diprediksi dapat menghasilkan kepadatan hingga 150-200 ind $/ \mathrm{ml}$. Pemberian ragi dengan komposisi yang tepat merupakan sumber nutrisi bagi Brachionus plicatilis untuk kehidupan dan perkembangbiakannya, karena penambahan ragi yang tepat pada media kultur menyediakan berbagai jenis protein, karbohidrat, dan jenis mineral (Yoshinaga et al., 1999). Rendahnya pertumbuhan pada penggunaan ragi bukan disebabkan rendahnya unsur nutrien yang ada dalam ragi, akan tetapi kurang tepatnya cara pemberian termasuk salah satu diantaranya adalah dosis yang tidak sesuai dengan kebutuhan proteinnya. Oleh karena itu dilakukan penelitian dengan tujuan untuk mengetahui dosis ragi roti yang terbaik dalam kultur Brachionus plicatilis.

\section{BAHAN DAN METODE}

Penelitian ini dilaksanakan pada bulan Juli - September 2015 di Laboratorium Mandiri Kecamatan Batu Layar Kabupaten Lombok Barat. Penelitian ini menggunakan Rancangan Acak Lengkap (RAL) yang terdiri dari 6 perlakuan dan diulang sebanyak 3 kali, sehingga diperoleh 18 unit percobaan yaitu perlakuan A: tanpa pakan, perlakuan B : pakan Nannochloropsis spp., perlakuan C : 0,0005 mg/individu, perlakuan D : 0,001 mg/individu, perlakuan $\mathrm{E}: 0,0015$ mg/individu, dan perlakuan $\mathrm{F}: 0,002$ mg/individu.

Rotifera yang digunakan adalah Brachionus plicatilis, fitoplankton adalah Nannochloropsis sp., dan ragi roti. Wadah dan media air laut yang digunakan sebelumnya disterilisasi terlebih dahulu sebelum digunakan. Kultur Nannochloropsis spp. dilakukan sebagai penyediaan pakan awal pada rotifera sebelum diberikana ragi. Kultur fitoplankton ini dilakukan pada wadah 20 L dengan pemberian pupuk UREA 40 ppm, ZA 50 ppm, TSP 10 ppm, $\mathrm{FeCl}_{3} 0,25$ ppm, dan EDTA 1,25 ppm sertadiberi aerasi. Kultur dimulai dengan kepadatan awal 5 juta sel/ml kemudian dipelihara selam 10-15 hari. Setiap empat hari dilakukan pemupukan susulan dengan konsentrasi pupuk yang sama dengan pemupukan awal.

Ragi yang digunakan sebagai pakan untuk Brachionus spp. adalah ragi roti yang diperkaya dengan minyak ikan dengan perbandingan 1:1 (Mokoginta et al., 2003). Total kebutuhan ragi roti per hari $(1,350 \mathrm{mg})$ dicampurkan dengan minyak ikan 0,8 mL kemudian didiamkan selama 24 jam pada suhu dingin agar minyak ikan terserap ke dalam ragi. Campuran ragi roti dengan minyak ikan dilarutkan dalam $100 \mathrm{~mL}$ aquades dengan perbandingan antara ragi dengan pengencer yaitu 0,032: $5(\mathrm{w} / \mathrm{v})$. Larutan ragi roti dihomogenisasi menggunakan sendok pengaduk kemudian dibiarkan selama 30 menit sebelum diberikan sebagai pakan untuk rotifera. 
Persiapan kultur Brachionus plicatilis menggunakan wadah dengan volume $20 \mathrm{~L}$ hingga mencapai kepadatan minimum $81 \mathrm{ind} / \mathrm{ml}$. Bibit B. plicatilis yang dibutuhkan pada penelitian ini sebanyak 1.620 .000 individu. Jika kepadatan per $\mathrm{mL}$ sudah mencapai minimum $81 \mathrm{ind} / \mathrm{mL}$ maka rotifera siap digunakan sebagai hewan uji. Kemudian ditebar dalam wadah toples sebanyak 18 buah dengan volume $1 \mathrm{~L}$ dengan kepadatan awal 15 ind/mL. Selama kultur yang berlangsung 14 hari diberikan pakan $2 \mathrm{x}$ sehari (pagi dan sore) berupa ragi dan nannochloripsis sp., dengan dosis sesuai perlakukan, dimana $7,5 \mathrm{mg} / \mathrm{L}$ untuk perlakuan $\mathrm{C} ; 15,0 \mathrm{mg} / \mathrm{L}$ untuk perlakuan D; 22,5 mg/L untuk perlakuan E; 30,0 $\mathrm{mg} / \mathrm{L}$ untuk perlakuan $\mathrm{F}$, untuk perlakuaan B hanya diberikan Nannochloropsis sp., dengan kepadatan $10.000 .000 \mathrm{sel} / \mathrm{mL}$ sampai ahir penelitian, sedangkan perlakuan A tidak diberikan pakan.

Pengamatan jumlah populasi

Brachionus spp. dilakukan setiap 24 jam menggunakan metode sampling dalam volume $500 \mu \mathrm{L}$. Pengambilan sampel menggunakan pipet mikro $250 \mu \mathrm{L}$. Untuk menginaktivasi hewan uji dilakukan penambahan klorin (bahan aktif 5,25\%) sebanyak $5-10 \%$ dari volume sampel. Pengamatan dilakukan dibawah mikroskop dimana sampel diletakan di dalam sedgwick rafter counter chamber. Data kepadatan digunakan untuk menganalisis pertumbuhan populasi yaitu konstante pertumbuhan spesifik $(\mu)$ ditentukan dengan menggunakan rumus $\mu=(\log C-$ $\left.\log C_{0}\right) /\left(t-t_{0}\right)(C=$ konsentrasi akhir pada masa pertumbuhan eksponensial, $C_{0}=$ konsentrasi awal pada masa pertumbuhan eksponensial, $\left(t-t_{0}\right)=$ rentang waktu. Waktu generasi (doubling time) dengan menggunakan rumus $t=\log (2) / \mu(\mathrm{t}=$ waktu generasi, hari).

Parameter kualitas air meliputi salinitas, derajat keasaman air $(\mathrm{pH})$, suhu, dan oksigen terlarut (DO) diukur pada awal dan akhir penelitian. Oksigen terlarut, salinitas, dan $\mathrm{pH}$ air diukur pada jam 12.00, sedangkan suhu diukur pada jam 06.00, 12.00, 18.00, dan 24.00. Pengukuran salinitas dilakukan dengan menggunakan refraktometer, $\mathrm{pH}$ menggunakan $\mathrm{pH}$ meter digital (ketelitian 0,01), suhu menggunakan termometer batang (raksa) dan oksigen terlarut menggunakan DO meter (ketelitian 0,01).

Data pertumbuhan populasi yang diperoleh dari penelitian dianalisis menggunakan analisis sidik ragam pada taraf nyata 5\%. Apabila hasil penelitian menunjukan perbedaan signifikan maka dilanjutkan dengan analisis beda nyata terkecil (BNT) pada taraf yang sama.

\section{HASIL DAN PEMBAHASAN}

Kepadatan populasi Brachionus plicatilis pada masing-masing perlakuan mengalami penurunan pada hari pertama, selanjutnya pada hari ke-2 mengalami peningkatan hingga mencapai kepadatan puncak pada hari ke-4 dan ke-5 (Gambar 1). Kepadatan puncak populasi tertinggi dicapai dengan pemberian pakan ragi roti sebanyak 30,0 mg/L yaitu 90,0 individu per $\mathrm{mL}$, diikuti dengan dosis $22,5 \mathrm{mg} / \mathrm{L}$ (54,3 individu per $\mathrm{mL}$ ), dosis $15,0 \mathrm{mg} / \mathrm{L}$ (40,7 individu per $\mathrm{mL}$ ) dan terendah pada dosis 7,5 mg/L (18,3 individu per $\mathrm{ml}$ ). Nannochloropsis spp. yang dijadikan sebagai kontrol perlakuan menghasilkan kepadatan populasi 17,7 individu per $\mathrm{mL}$. Pada perlakuan tanpa pakan, Brachionus hanya terlihat hingga hari ke-2. 


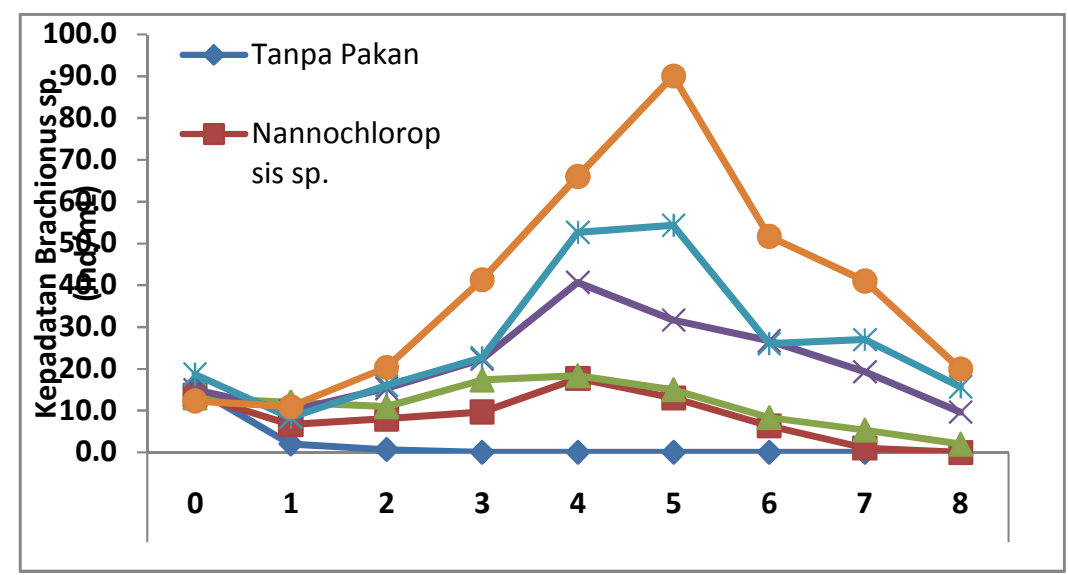

Gambar 1. Kepadatan Puncak Populasi Brachionus plicatilis

Berdasarkan analisis sidik ragam, perbedaan dosis ragi roti memberikan pengaruh secara signifikan terhadap pertumbuhan populasi dan waktu generasi Brachionus plicatilis. Hasil uji lanjut menggunakan uji BNT, diperoleh bahwa dosis 30,0 ppm memberikan kepadatan populasi tertinggi dan waktu generasi yang paling singkat dibandingkan dengan lima perlakuan lainnya (Gambar 2 dan 3).

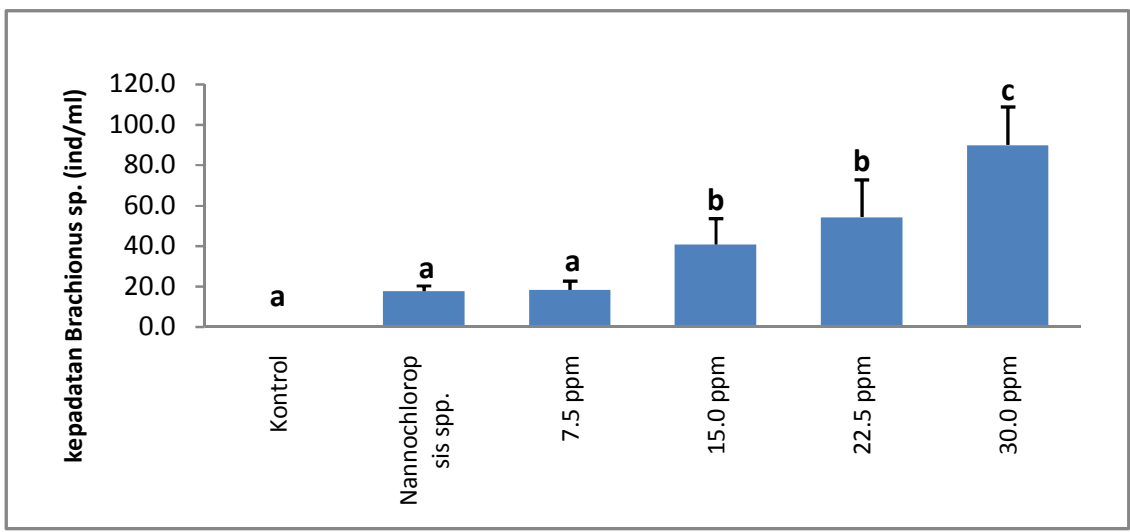

Gambar 2. Rata-rata Kepadatan Populasi Brachionus plicatilis 


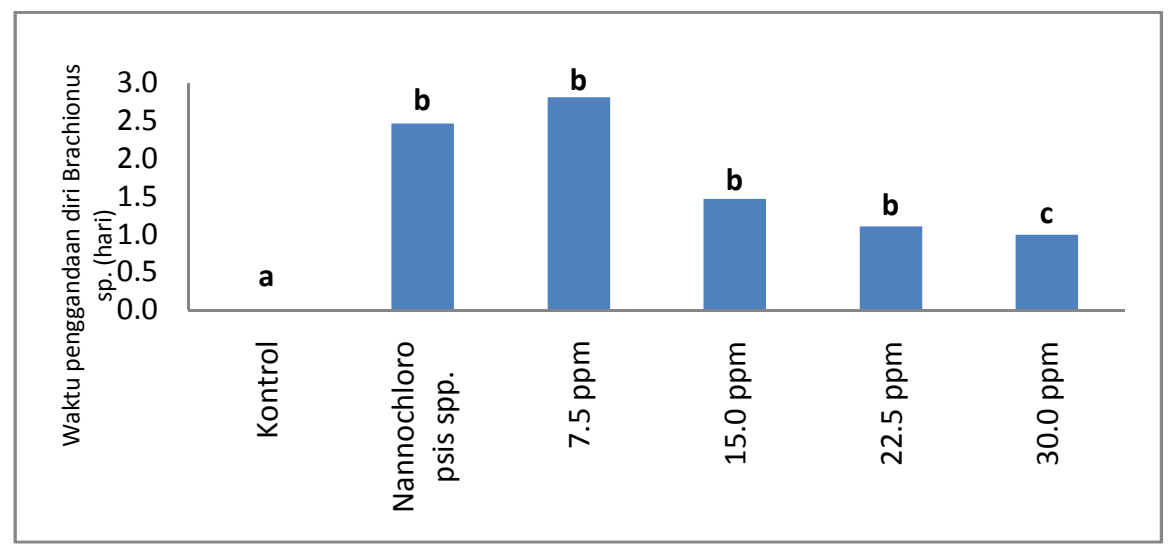

Gambar 3. Rata-rata Waktu Generasi Brachionus plicatilis.

Rata-rata waktu yang dibutuhkan Brachionus plicatilis untuk mencapai kepadatan puncak terlihat berbeda-beda pada masing-masing dosis ragi roti (beaker yeast) yang diberikan. Perbedaan waktu pencapaian kepadatan puncak dalam penelitian ini diduga disebabkan oleh adanya perbedaan ketersediaan jumlah makanan yang menjadi sumber nutrisi yang ada dalam media kultur sehingga dapat mempengaruhi pertumbuhan Brachionus plicatilis pada tiap perlakuan. Yoshinaga et al., (1999) menyatakan bahwa pemberian ragi roti dengan komposisi yang tepat merupakan sumber nutrisi bagi Brachionus plicatilis untuk kehidupan dan perkembangbiakannya, karena dengan penambahan ragi roti yang tepat pada media kultur maka akan dapat menyediakan berbagai jenis protein, karbohidrat, dan jenis mineral.

Setelah pertumbuhan populasi mencapai puncak, maka tidak terjadi penambahan individu lagi karena laju pertumbuhan seimbang dengan laju kematian (fase stasioner). Setiap perlakuan memperlihatkan penurunan kepadatan populasi yang berbeda-beda. Pemberian ragi roti dosis $30 \mathrm{ppm}$ dan 22,5 ppm mengalami penurunan yang tajam setelah melewati kepadatan puncak dimana masing-masing perlakuan mengalami penurunan sebesar $42,6 \%$ dan $52,1 \%$ dari kepadatan pada hari sebelumnya (kepadatan puncak). Pada tiga perlakuan lainnya penurunan kepadatan populasi terlihat lebih rendah yaitu $22,1 \%$ untuk dosis ragi roti 15 ppm, 18,1\% untuk dosis ragi roti 7,5 ppm dan $26,4 \%$ untuk pakan Nannochloropsis spp. Penurunan pertumbuhan populasi terus berlangsung seiring dengan bertambahnya waktu kultur dimana laju kematian terjadi lebih tinggi dari laju pertumbuhan atau mengalami fase kematian. Penurunan kepadatan populasi yang terus berlangsung diduga disebabkan 
oleh ketersediaan pakan dalam media yang sudah tidak mencukupi kebutuhan Brachionus spp.

Selama pemeliharaan tidak dilakukan penambahan dosis pakan sehingga dengan semakin meningkatnya jumlah populasi maka ketersediaan pakan per individu Brachionus spp akan menurun. Pada dosis 30,0 ppm dimana kepadatan populasi tertinggi yang dicapai pada hari ke-lima sebesar 90 individu per ml ketersediaan pakan dalam media tumbuh bervolume $8 \mathrm{~L}$ adalah $0,33 \times 10^{-6}$ g/individu lebih rendah dari yang disarankan oleh Arimoro (2006) dimana untuk penggunaan ragi roti sebagai pakan Brachionus spp. dosis yang disarankan adalah $1,0 \times 10^{-6} \mathrm{~g} / \mathrm{individu}$. Meskipun dalam perlakuan ini dosis perlakuan pada awal kultur telah ditingkatkan sebanyak $100 \%$ yaitu $2 \times 10^{-6}$ g/individu namun karena jumlah pakan yang diberikan ditetapkan pada kosentrasi 30,0 mg/L maka dengan bertambahnya jumlah populasi Brachionus spp., ketersediaan pakan semakin tidak mencukupi kebutuhan pakan per individu. Berdasarkan hal ini maka dalam pemberian pakan perlu memperhatikan kebutuhan pakan per individu yang konstan agar masa pertumbuhan bisa dipertahankan lebih lama dengan kepadatan populasi yang lebih tinggi.
Kualitas air selama penelitian memiliki kisaran yang sama disemua perlakuan sehingga tidak mempengaruhi pertumbuhan Brachionus plicatilis pada setiap perlakuan. Salinitas pada penelitian ini masih pada kisaran optimal yaitu 33-35 ppt. Salinitas mempunyai pengaruh yang sangat kuat terhadap derajat reproduksi Brachionus plikatilis. Bila jenis dan ukuran Brachionus plicatilis berbeda maka salinitas optimalnya juga akan berbeda (Lubzens, 1987). Brachionus plicatilis termasuk euryhaline sehingga memiliki toleransi salinitas lebar (Fielder et al., 2000; Suminto, 2005), namun akan mengalami perkembangan terbaik pada salinitas antara 10-20 ppt, sedangkan salinitas diatas $35 \mathrm{ppt}$ akan mencegah terjadinya reproduksi seksual, pencegahan ini merupakan hal yang diinginkan dalam kultur massal disebabkan karena keberadaan individu jantan dan kista akan mengurangi tingkat pertumbuhan populasi dan hasil panen secara keseluruhan.

Kisaran suhu masih dalam ambang optimal bagi pertumbuhan Brachionus plicatilis yaitu kisaran $25-27{ }^{\circ} \mathrm{C}$. Menurut Isnansetyo dan Kurniastuty (1995), bahwa kisaran suhu yang optimum untuk pertumbuhan dan reproduksi Brachionus plicatilis yaitu berkisar antara $22^{0}-30^{\circ} \mathrm{C}$. Kisaran $\mathrm{pH}$ yang diperoleh pada semua perlakuan masih dalam kisaran yang baik untuk pertumbuhan Brachionus plicatilis 
yaitu 7,7-7,9 dan oksigen terlarut 7,1-7,5. sehingga dapat disimpulkan tidak mempengaruhi pertumbuhan pada setiap perlakuan. Menurut Redjeki (1999) kualitas air merupakan salah satu faktor penting yang dapat menyebabkan perubahan tingkah laku organisme perairan dan dapat mempengaruhi tingkat nafsu makan berkurang atau sebaliknya, pertumbuhan lambat atau cepat, dan adanya gangguan hama dan penyakit yang akhirnya dapat mempengaruhi kelangsungan hidup termasuk Brachionus plicatilis. Pertumbuhan Brachionus plicatilis juga sangat dipengaruhi oleh kualitas air diantaranya yaitu $\mathrm{pH}$, oksigen terlarut, karbondioksida dan salinitas.

\section{KESIMPULAN}

Perbedaan dosis ragi roti berpengaruh nyata terhadap pertumbuhan populasi Brachionus plicatilis, dimana kepadatan populasi tertinggi diperoleh pada dosis ragi 30,0 $\mathrm{mg} / \mathrm{L}$ yaitu 90 individu/mL. Dengan demikian, pemberian ragi roti sebagai pakan Brachionus plicatilis sebaiknya dilakukan pada dosis 30,0 ppm dan selama pemeliharaan perlu memperhatikan kebutuhan pakan yang konstan dengan cara meningkatkan dosis pakan secara bertahap sesuai dengan pertumbuhan populasi Brachionus plicatilis didalam media pemeliharaaan.

\section{DAFTAR PUSTAKA}

Arimoro, F.O. 2006. Culture of the freshwater rotifer, Brachionus calyciflorus, and its application in fish larviculture technology. African Journal of Biotechnology. 5 (7): 536$541 .$.

Astuti, P. R., S.L. Sagala, Gunawan, G.S. Sumiarsa, S., dan P.T. Imanto. 2012. Optimasi Dosis dan Frekuensi Pakan Dalam Produksi Rotifer (Branchionus plicatilis). Jurnal Ilmu dan Teknologi Kelautan Tropis, 4 (2): 239-246.

Chilmawati, D. dan Suminto. 2009. Pengaruh Penggunaan Ragi Roti, Vitamin B12, Vitamin C Sebagai Bahan Pengkaya Pakan Terhadap Populasi Branchionus plicatilis. Jurnal Saintek Perikanan. 5 (2): 47 53.

Dhert, P. 1996. Rotifers. In : P. Lavens and P. Sorgeloos (ed). Manual on the production and use of live food for aquaculture. FAO Fisheries Technical Paper, 361. FAO, Rome : 49 - 77.

Dhert, P., G. Rombaut, G. Suantika, and P. Sorgeloos. 2001. Advancement of rotifer culture and manipulation techniques in Europe. Aquaculture, 2000 (2001) : 129-146.

Fielder, D.S., G.J. Purser, and S.C. Battaglene. 2000. Effect of rapid changes in temperatur and salinity on availability of the rotifer Branchionus rotundiformis and 
Branchionus plicatilis. Aquaculture, 189 (2000) : 85-99.

Fitriani, S.H, D. Bakti, Nurmatias. 2013. Pengaruh Beberapa Jenis Pakan Terhadap Pertumbuhan Populasi Branchionus spp. Aquacoastmarine. 3 (2): 33-43.

Haryanti. 2002. Teknik Produksi Pakan Alami. Balai Riset Perikanan Budidaya Laut, Gondol, Bali. 15 p.

Isnansetyo, A. dan Kurniastuty. 1995. Teknik Kultur Phytoplankton \& Zooplankton. Penerbit Kanisius. 116 p.

Khaeriyah, A. 2014. Optimasi Pemberian Kombinasi Fitoplankton dan Ragi dengan Dosis yang Berbeda Terhadap Pertumbuhan rotifer (Branchionus plicatilis sp.). Jurnal Balik Diwa. 5 (1): 14-19

Lubzens, E. 1987. Raising Rotifers for Use in Aquaculture. Hydrobiologia. 147: 245-255.

Lubzens, E., A. Tanler, and G. Minkoff. 1989. Rotifer as food in aquaculture. Hydrobiologia, 186/187 : 387-400.

Melianawati, R., A. Hanafi, dan M. Suastika. 2006. Pengaruh Perbedaan Jenis Pakan Terhadap Pertumbuhan Populasi Branchionus plicatilis. Jurnal Perikanan (J. Fish. Sci.) 8 (1): 118-123.

Mokoginta, I., D. Jusadi, T.L. Pelawi. 2003. Pengaruh Pemberian Daphnia sp. Yang di Perkaya Dengan Sumber Lemak Yang Berbeda Terhadap Kelangsungan Hidup dan Pertumbuhan Larva Ikan Nila,
Oreochronis niloticus. Jurnal Akuakultur Indonesia. 2.(1): 7-11.

Pranata, A. 2009. Laju Pertumbuhan Populasi Rotifer (Branchionus plicatilis) Pada Media Kombinasi Kotoran Ayam, Pupuk Urea dan TSP, Serta Penambahan Beberapa Variasi Ragi Roti. Skripsi. Fakultas Matematika dan Ilmu Pengetahuan Alam, Universitas Sumatera Utara. $37 \mathrm{Hal}$.

Redjeki, S. 1999. Budidaya Rotifera (Branchionus plicatilis). Oseana. 24 (2): 27-33.

Sahandi, J., and H. Jafaryan. 2011. Rotifer (Branchionus plicatilis) culture in batch system with suspension of algae (Nannochloropsis oculata) and bakery yeast (Saccharomyces cerevisiae). AACL Bioflux, 4(4) : 526-529.

Suminto. 2005. Budidaya Pakan Alami Mikroalgae dan Rotifer. Universitas Diponegoro. Program Studi Budidaya Perairan, Jurusan Perikanan, Fakultas Perikanan dan Ilmu Kelautan. Buku Ajar Mata Kuliah Budidaya Pakan Alami. 72 Hal.

Warouw, V. 2010. Memaksimalkan Potensi Dormansi Pada Rotifer Branchionus rotundiformius Melalui Mating Eksperiment. Jurnal Perikanan dan Kelautan. 6 (1): 31-35.

Widjaja, F. 2004. Pendayagunaan Rotifera yang Diberi Pakan Alami Berbagai Jenis Mikroalgae. Jurnal Ilmu-ilmu Perairan dan Perikanan Indonesia. 11 (1): 23-27. 
Wohlshlag, N.S., L. Maotang and C.R. Arnold. 1990. Raising Food Organisms for Intensive Larval Culture: II. Rotifer. In : Red Drum Aquaculture. Texas A\&M Sea Grant College Program No. TAMU-SG90-603.p.66-70.
Yoshinaga, T., A. Hagiwara, \& K.

Tsukamoto. 1999. Effect Of Conditiones media on the asexual reproduction of the monogont rotifer Branchionus plicatilis O.F. Muller. Hydrobiologia. 412:103-110. 